Rwanda Journal ISSN 2305-2678 (Print); ISSN 2305-5944 (Online)

DOI: https://dx.doi.org/10.4314/rj.v2i1.6A

\title{
Teaching academic writing to first year university students: a case study of feedback practicesat the former National University of Rwanda
}

Innocent Twagilimana, University of Rwanda, College of Education. Postal Address: PO Box 5039, Kigali, Rwanda. Tel.: +250787684457. E-mail: twagilin@gmail.com

\begin{abstract}
Research has pointed out that assessment practices related to academic writing are often unclear to students and this has consequences to their styles of learning hence the overall outcomes of their university studies (Lillis, 2006, 1999; Ivanič, 1998; Lea \& Street, 1998). The purpose of this paper is to critically examine to what extent feedback practices - as part of the strategies used in assessment of student work - are meaningful to the expected learning process. The study draws on a set of theories including development of student writing (Coffin et al., 2003), teacher feedback practices (Brown et al., 1997) and academic literacies in English as Second Language (Zamel, 2011), and uses qualitative case study methodology. Data are collected through analysis of key documents including student scripts, observation of classes and interviews of all lecturers involved in the concerned setting and a sample of 16 students. Findings reveal that the evaluated students are not likely to make appropriate use of assessment to improve their writing as the type of feedback practices observed is surrounded with confusion regarding what the lecturers' expectations are and hence what is required of an academically acceptable text. It is recommended to open more space for a "dialogue of participation" with students to ensure their familiarity with the discourse strategies that are critical to the writing competences expected of them at university.
\end{abstract}

Key words:English as second language, academic writing, first year university students, feedback practices, student assessment, Rwanda.

\section{Introduction}

This paper reports on findings of a research study conducted at the former National University of Rwanda (henceforth NUR) ${ }^{\mathrm{i}}$. The study was part of a doctoral research project and was aimed at examining feedback practices related to students' academic written work. Interest in this study was mainly aroused by previous studies reporting problems related to students' writing abilities in the Rwandan higher education institutions (Rosendal, 2009; NCHE, 2007b) ${ }^{\mathrm{ii}}$.As similar problems were also reported internationally (Angelil-Carter, 1998; Lillis \& Turner, 2001), it was judged useful to examine the way in which student academic writing is dealt with in the concerned institutions based on a case study carried out at the former NUR. The research focused on a particular academic writing course ${ }^{\mathrm{iii}}$ taught to first year university students. 
Actually, much is at stake in a Second Language (L2) context such as Rwanda where possible limited English proficiencies of students $\left(\mathrm{NCHE}^{\mathrm{iv}}, 2007 \mathrm{~b}\right)$ would constitute a challenge to the "quality of higher education" so cherished by the Rwandan government ${ }^{\mathrm{v}}$.Yet, writing skills are of paramount importance for the success of academic endeavour as they help students not only to perform in the academic writing tasks expected of them, but also to be able to think critically and learn in maximum from the subject matters they are engaged in (Langer \& Applebee, 2007).

Concerned authorities seem to be aware of the situation, and attempts have been undertaken to address the language issue in higher education institutions. Thus, a national policy for language teaching has been established to help "every student swiftly bring his or her grasp of [English] up to the level where they can participate in academic activities and learn from lectures" (NCHE, 2007a, p. 1). It is thus in application of this policy that students entering first year at NUR aregiven special literacy courses meant to prepare them for academic activities conducted in English. The investigated module is specifically focused on academic writing ${ }^{\mathrm{vi}}$. In the investigated provision, the module was generic - not discipline-specific, and it was up to the teaching team to adapt the teaching content and approach to students. So, this may constitute a challenge for the teaching team as not only methodological competences but also updated knowledge of theoretical principles of academic literacy were needed to help students "reach the required standard" (NUR, 2009, p. 1). The present study is intended to explore the way in which this writing module is preparing students to overcome writing challenges they are likely to be confronted with during their degree studies at university. A particular focus is put on feedback practices carried out by lecturers during the course.

\section{Theoretical perspective}

Assessment practices surrounding academic activities are expected to encompass a formative function ${ }^{\text {vii }}$ meant to provide feedback to students to help the lecturer achieve his/her goal in terms of improvement of students' abilities in the target discipline. Indeed, formative assessment, as opposed to summative assessment, has been pointed out as the way to go for improvement of students' abilities as "it has a teaching function, to help students improve their work rather than just measure their achievements" (Coffin et al., 2003, p. 76). Formative assessment may also help ensure a quality teaching in the sense it 
can help the lecturer get a clear idea of students' difficulties and the type of assistance they need.

However, as has been pointed out by research, assessment practices related to academic writing are often unclear to students (see Ivanič, 1998; Lea \& Street, 1998; Lillis, 1999). This is particularly true with students whose native language is not the language of instruction - English, in the case of the current study - who are least likely to be familiar with the conventions of academic writing in English (Coffin et al., 2003; Zamel, 1998). In higher education, this group is generally made of students who may have experience of different forms of written assessment and, hence, have different expectations from those of their teachers or evaluators.

Students of this category are indeed faced with particular challenges which can affect the overall outcomes of their university studies. Thus, given the role of assessment methods in influencing styles of learning and, hence, the outcomes expected of the learning/teaching process (see Brown et al., 1997), adequate strategies must be established in order for the assessment of students' writing to be meaningful to them. These strategies will particularly concern assessment criteria, guidance on assignment task, and feedback to students' work.

Criteriagenerally refer to "dimensions of an assignment that are assessed such as organisation, style, use of evidence" (Brown et al., 1997, p. 42). With regard to writing, dimensions with which the quality of students' text is judged need to be established in relation to the assessment task and the outcomes expected of the learning/teaching process. To such an end, lecturers need to have a clear idea of learning outcome(s) expected as well as the specific requirements of the assessment methods that will be used. While it is possible for lecturers to use criteria without showing them to students, Coffin et al. (2003) suggest that assessment criteria should be made transparent and presented to students ahead of their writing task. These authors note that there are several ways in which criteria may be related to marking. They provide an example of broad marking criteria devised for essays written on English language course:

- the relevance of your answer to the question as set;

- your knowledge and understanding of the course material; 
- $\quad$ ability to discuss and evaluate alternative explanations and arguments;

- $\quad$ ability to present and pursue an argument;

- ability to express yourself clearly using academic conventions as appropriate;

- clarity in your work, in the way you make your points, present research finding and make critical comments. You are not expected to make extensive use of technical vocabulary, but you should be able to refer to key terms and concepts from the course materials. You should also acknowledge clearly any sources you have drawn on.

The example of criteria above, which are relatively open, appears relevant for an academic essay which is generally regarded as a high-level practical task. As suggested by Brown et al. (1997), detailed criteria are rather useful for research than teaching purposes. The use of detailed lists of criteria is too demanding in terms of time consumption, and needs a good level of mastery on the part of the assessor if the marks allocated to students' writing are to be valid. The use of broad and relatively open criteria has the advantage of ensuring flexibility in allocating marks to students' essays whose various aspects cannot be assessed without involvement of 'judgment and a certain degree of 'impression marking' (Coffin et al., 2003). This use of open criteria in fact constitutes a further reason for ensuring a common understanding with students ahead of the writing task in relation to what will be valued in their texts.

Apart from assessment criteria and guidance ahead of writing tasks, the necessity to help students improve their learning also requires provision of feedback. The latter is actually one of the central pedagogic practices at all level of education, and it is often regarded as part of the evaluating process (Lillis, 2003). Feedback is also object of attention on the part of bodies in charge of quality assurance in different universities where principles governing provision of feedback on assessed work are sometimes outlined as a strategy of optimising students' benefit from feedback. This is for example the case for the Quality Assurance Agency (QAA) in the UK (Coffin et al., 2003).

While one of the qualities of feedback is to be meaningful and acceptable to the receiver (Brown et al., 1997), research on feedback suggests that it is a complex process that needs 
to be undertaken with attention in order to reach the expected objective which is to encourage the receiver to think and, if necessary, to change. Coffin et al. (2003, p. 103) present points of broad consensus, from a range of research studies, in relation to the challenges the endeavour of providing feedback to students' work is often confronted with:

- the purposes of feedback are often mixed and left unstated;

- there is often a mismatch between lecturers' and students' understanding about what is required in academic writing;

- students may find lecturers' comments unclear, confusing, vague;

- students may meet with different (and inconsistent) comments from different lecturers on similar pieces of writing;

- the kinds of feedback lecturers provide, and the way this is expressed, are informed by lecturers' disciplinary backgrounds, personal interests and values;

- feedback does not always correspond to published guidelines or criteria;

- feedback is often not as helpful as either lecturers or students would like it to be;

- giving and receiving feedback is an emotional, as well as a rational activity.

There are in fact continuing debates over important issues surrounding feedback: what kind of feedback is most useful to students? Do students make use of feedback comments or are they primarily interested in grade? What is the most effective way of wording comments on students' work? Etc. The fact is that students' understanding of feedback is surrounded with much confusion (Coffin et al., 2003). So, it is important to keep aligned with the main purpose of assessment and the comments to be made on students' assignment.

It is also important to consider the relevant way of communicating feedback to students because, as suggested by Coffin et al. (2003), "particular ways of communicating feedback contribute (...) to students' understanding of the comments they receive; to what they feel about these comments; and to the establishment of a particular kind of relationship between lecturer and students, or, more generally, those who give and receive feedback" (p. 111). Positive comments are for example important in the sense that students need to be aware of their strengths in addition to their awareness of the aspects to be improved in 
their writing. The language of feedback may also constitute a critical factor in the establishment of positive or negative power relations between lecturers and students: it can contribute in the building of a relatively hierarchical and didactic relationship with emphasis on the power differential between lecturer and students; or a more collegial relationship in which "students' sense of membership of the academic community" is established (Ivanič et al., 2000, p. 61).

\section{Research methods}

The study used a case study perspective striving to understand the issue under examination in its natural setting with a particular attention to contextual conditions and experience of the participants (Lacono, Brown, \& Holtham, 2009). To such an end, the selection of the research site was made according not only to the suitability of the case for the research aim, but also to the typicality hence the significance of the former NUR as a higher learning institution in Rwanda. Indeed, the former NUR as a higher learning institution was the oldest, the largest, and the most diversified in terms of possibilities of academic options in the country. It was thus the most likely to stand as an interesting representative of literacy practices in the national higher education system.

\subsection{Sampling}

The study used a purposeful sampling strategy focusing on information-rich key participants including both students and lecturers who took part in the study. For student participants, the socio-linguistic or educational backgrounds, as well as the willingness to participate, were the primary considerations in identifying participants for the investigation. The researcher made sure all categories of students (in terms of socio-linguistic and/or educational background) were represented in the selected sample. In fact, since the adoption in 2008 of English as the only medium of instruction at almost all levels of education in Rwanda, students with a French speaking school background merged with classmates with an English speaking school background $^{\text {viii }}$. The criterion related to the language background was thus of interest for the researcher and it was taken into account for research sampling.

For the whole cohort of 86 students involved in the module, $20 \%$ of student participants (i.e. 16 students) were purposefully selected and interviewed. All three members of the teaching team also participated in the investigation which involved the Director of Academic Quality unit as 
well.So, as generalisability of the findings was not the purpose in the present case study, the purposeful sampling strategy was applied to the site selection as well as to the selection of the students who took part in the study.The limited number of the concerned lecturers was compensated by a prolonged time spent on the field by the researcher. That is, the researcher was continually returning to the same participants with the purpose of 'checking veracity' and consistency of the information collected.

\subsection{Data collection methods and instruments}

The data collection process used document analysis, classroom observations, and interviews as data collection methods. As qualitative research is interactive and requiring a relatively extensive amount of time to systematically observe, interview, and record processes as they occur naturally, such a condition was met through the whole process of data collection. Indeed, the time duration for data collection was the entire three-month period (from February to April 2011) during which the investigated module was taught for the academic year 2011.

Data collection strategies ${ }^{\mathrm{ix}}$ focused on understanding of the experience under investigation with a particular attention to what it meant to participants. Further, in order to increase validity of findings, the researcher used a multi-method strategy assuming that "any data can be corroborated during data collection” (McMillan \& Schumacher, 2006, p. 340). That is why, without necessarily interfering as field worker, the researcher endeavoured to seek different views about the collected pieces of information from a number of participants for accuracy and for confirmation.

\subsubsection{Document analysis}

An analysis of different documents related to the design and the daily management of the module was conducted. These documents includedsamples of students' writing with written feedback by lecturers, assignment guidelines, anecdotal comments from lecturers, etc.Analysis of this kind of documents provided information related to the type of assumptions underpinning the existing texts, the degree of openness (or clarity) of working instructions/guidance, the status of the assessment criteria, the type of feedback, etc.

\subsubsection{Observation of the teaching and learning process}


The researcher made use of field observation ${ }^{\mathrm{x}}$, and interviewing in this context was conducted in a form of informal conversations with some participants ${ }^{\mathrm{xi}}$. As for artefacts collection, they were particularly related to documents that were continuously collected during the entire period of the researcher's presence in the site. So, informal conversations and artefact gathering served as corroborative data collection strategies (McMillan \& Schumacher, 2006, p. 332).

\subsubsection{Interviews}

For both teaching staff and students, qualitative interviews essentially based on interview guide approach were privileged. That is, topics were selected in advance, but the researcher decided the sequence and wording of the questions during the interview (McMillan \& Schumacher, 2006). In other words, there was no standardised format for questions. The researcher counted rather on a conversational tone - characterised by probes ${ }^{\mathrm{xii}}$ and pauses - to ensure the naturalness and relevancy of the response. The use of open-ended questions thus created possibility of alternative views and access to data that would not be accessible in other ways. Information obtained from observation sessions could also be verified. Two types of data collection instruments were used for the interviews: an interview guide (a semi-structured interview) and post-observation session discussions between the researcher and the participants.

\subsection{Data analysis}

Data collected through document analysis, classroom observation and interviews were described and categorised in terms of typical patterns or recurrent characteristics. Results were interpreted with reference to the existing literature and the theoretical framework established for the study. The analytical criteria having inspired initial coding and categorisation were derived from the concepts informing the study. Thus, feedback practices used by lecturers were critically analysed through the lens of the theoretical perspectives or models on how the meaning making skills are expected to be developed (Lillis, 2001; Lea \& Street, 1998; NLG, 1996). The results of analysis also benefited from a triangulation with students' accounts of their experience with academic writing tasks.

\section{Main findings of the study}

The teaching process observed consisted in a four-hour session per week, and was observed from February 10 to April 6, 2011. The first-year cohort consisted of 86 students who were alternatively taught by three lecturers. Concerning tasks performed by students, a certain 
shortage of activities leading to text production was perceptible as the course was mainly focused on presentation of notions related to textual structure (e.g. introduction, conclusion, writing of a paragraph...), and surface language features such as spelling, punctuation, etc. The rare practical tasks assigned to students were based on take-home assignments which benefited from lecturer's feedback in a form of classroom discussion with students. The current section analyses the type of feedback provided to student work. The analysis is carried out in relation to the written feedback as well as that made in oral form throughout the observed teaching process.

\subsection{Feedback not always in line with the objective of the assigned task}

On analysis of the form of feedback used for the investigated module, one may wonder whether there is a certain pedagogical purpose underpinning the type of comments made on students' writing. Indeed,feedback comments made on student texts do not show consonance with any informed pedagogical agenda to support students' learning. Some of the comments are not explicit and appear as just meant to justify the marks awarded. Further, a significant amount of comments made are not in line with the objective of the assigned task as reflected by the assignment question. In other words, feedback comments made on students' work do not seem to inscribe themselves in a learning improvement perspective set in advance by the lecturer. The type of comments produced on student scripts below serve as examples:

\footnotetext{
${ }^{\mathrm{i}}$ The former National University of Rwanda (NUR) has since 2013 changed in favor of a one university system, the University of Rwanda (UR), as result of merger of seven public higher education institutions.

${ }^{\mathrm{ii}}$ This is also corroborated by statements in the press and informal lecturers' talk.

iii Principles of anonymity for research participants dictate withholding details of the concerned module.

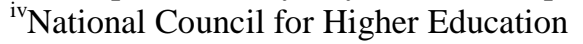

${ }^{v}$ Different sources, including the appraisal document of the Rwandan Education Strategic Plan 2010-2015

(MINEDUC, 2010), the World Bank (2011), and a content analysis of some critical policy documents related to the Rwandan education system (Baxter, 2012) have indicated a high priority given by the government to the issue of "quality of higher education".

${ }^{\mathrm{vi}}$ Some other courses - such as the 'Oral and Written Expressions in English' - are only partially related to academic writing as a part of the content is rather oriented to oral expression.

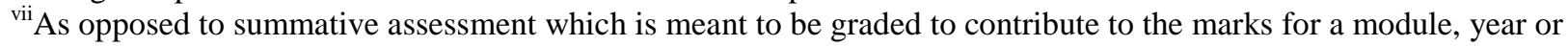
degree (Brown et al., 1997).

viii The Rwandan sociolinguistic context, following the massive return in the country of 'ancient' refugees after 1994, gave place to what was termed 'bilingual' educational system where Francophone schools existed alongside Anglophone schools.
} 


\footnotetext{
ix The term 'strategies' is opposite to procedures, and is referring to "sampling and data collection techniques that are continuously being refined throughout the data collection process to increase data validity" (McMillan \& Schumacher, 2006, p. 340).

"With reference to the "technique of directly observing and recording without interaction" (McMillan \& Schumacher, 2006, p.346).

${ }^{\mathrm{xi}}$ Focus group sessions were also organised with students.

xii "Interview probes elicit elaboration of detail, further explanations, and clarification of responses" (McMillan \& Schumacher, 2006, p. 354).
} 


\section{$65 / 10$ The in portance of Literature}

storytliling: the all hinds of value arts,

Fo break the Ne, literature is ploys. In this essoup we are gring such as scorples poems and proys portant to people, and how

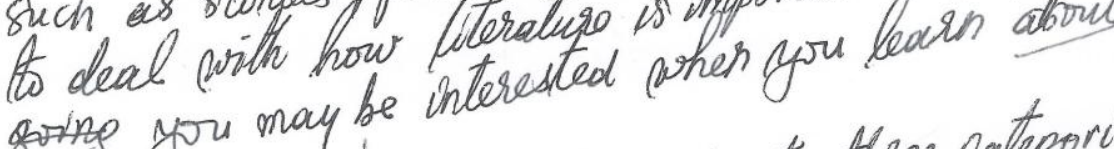
going you may be interest. three cateovies such as

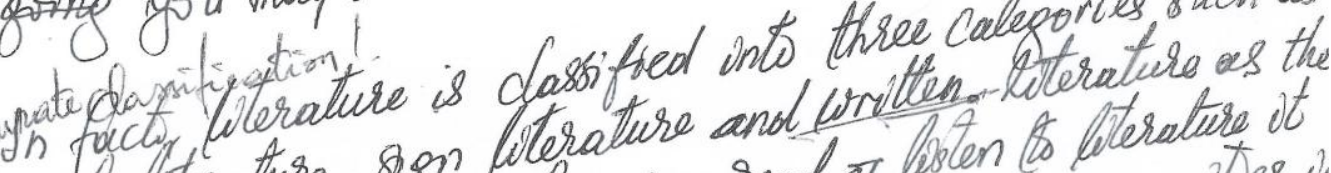
oral fiterature, sign fiteran you read or cesten to fiterature ot

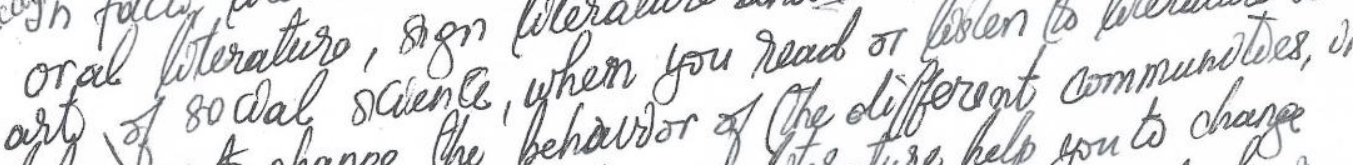
help wou to change the behaw vever Wterature help you to change

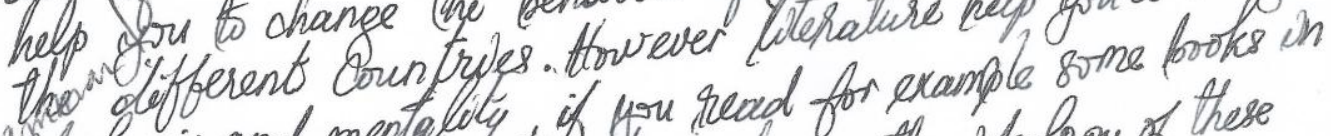

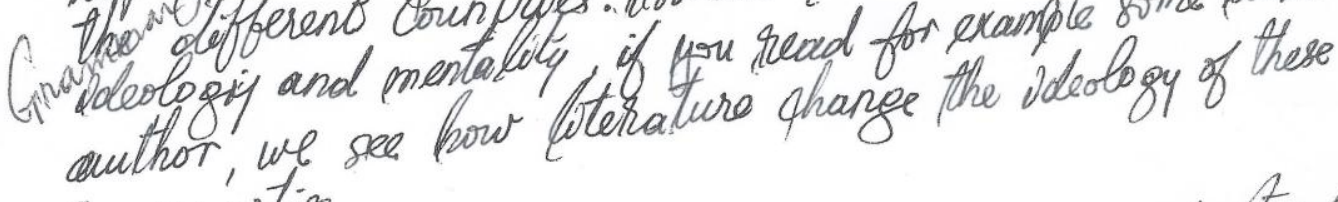
Communoties.

Fr instance of you listen play on the radso you understand som behaviors as well as good and bad. Kaorever you chooss the grod way apd avoid bad poun. On the other hand bhe bolving some impory tant in owr stociety fecause is, there are some foroks and problems. Il our society, for example, chere are som conflicts. stories which ore gosing some solutions in maing Astecturing others, In our country Heratire concern arth African Dolcrature (National

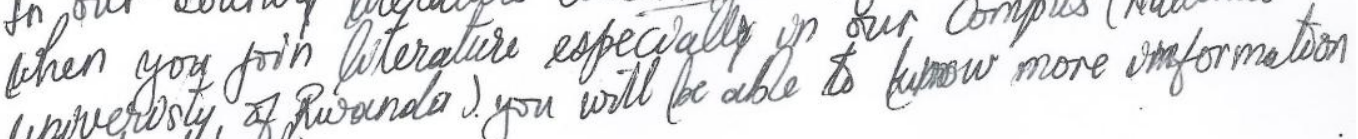

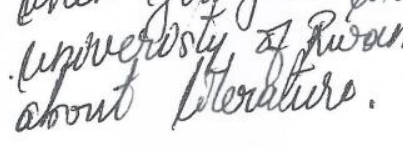

In sum, Cuterature plays greab role in our doaily life because. goves you some instructions and educatoon in our decoly life.

$$
\text { - Fartity graminang sentences, Conjugation... }
$$


cares to Billy in the way that Billy could not escape this love until now their love is still strong. After the university studies Billy found a job. He was an interpreter in Serena hotel Kigali .he passed an exam and became the first. That how he found a job.

He worked there for a period of five years and him also doing his masters degree in USA in information and communication skills. While working at Serena hotel many beautiful girls tried to fall in love with Billy but in vain. He had promised Bubu to be her father's children, that's why he could never deceive his fiancé.

One of these girls even promised him a car but he denied the gift because he knew this will be dangerous to him the time for wedding ceremony arrived, the family of Billy and Bubu'gathered to celebrate their children's party, in their honey moon the new couple had a trip to Kivu sun beach to relax and plan for the new life, they had their own house, car and many other properties.

After two years they had their first child, this was a great pleasure to their family, they had their family planning so that they could never go beyond 2 children. After leaving the second born they decided to send their children abroad, their children were very intelligent, they all come first in their classes. Billy and Bubu are now a happiest family in the world, every body wishes to be like them.

In short, Billy faced a challenged life when he was still young. You can't imagine. the way he overcomes those struggles it's a long way. If he didn't take care of himself he wouldn't become a man he is now. Many people face struggle in their lives but a few of them successes. Billy at the end of his life will be a hero; everybody who knows him will try to imitate him. At the end of my story, I encourage people to take care of themselves like Billy of this story did.

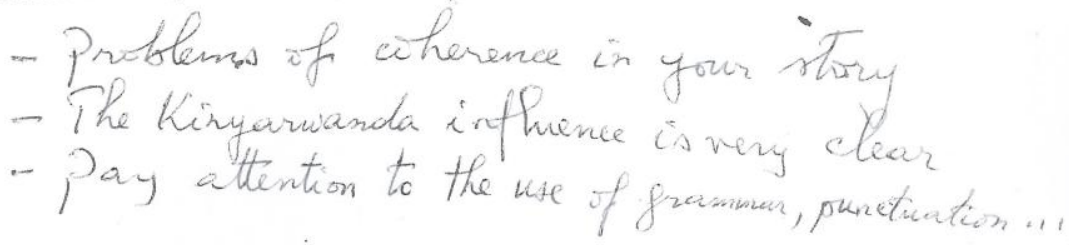


As illustrated by the student scripts above, a discrepancy can be noticed between the assignment question (which is directed to the content or the student-writer's understanding and treatment of the topic) and the lecturers' feedback comments (which are focused on the linguistic accuracy or just the surface features of the text). This also serves as indication that lecturers' comments do not reflect a consistent purpose with regard to students' needs in terms of writing abilities. Surface language features such as spelling, punctuation, and the set of notions referred to as "grammar" including conjugation, sentence structure, etc. remain the main focus of lecturers' comments on the student scripts while features such as argument and supporting evidences, which are nevertheless important in essay texts, are not evoked by the feedback comments made by the lecturer. Thus, the evaluated students are not likely to make appropriate use of the feedback to improve their writing. They are rather likely to be confused with regard to what the lecturers' requirements are and hence what is required of an academically acceptable text.

In addition, the way in which most of feedback comments are expressed is rather not explicit and reflects a discourse of academic transparency based on assumption that the understanding and the enactment of the academic writing conventions are self-evident. For the observed sessions, such a view is typified by the incessant calls to exercise a series of skills generally taken as given by lecturers such as coherence, clarity, good structure, etc. The remarks made by lecturers in relation to a sample of students' written texts may serve as illustrative examples: "When you're writing an essay for instance, you'll make sure that your title is short and really attractive" (Week Four: 10/03/2011). This is probably easier said than done. In this last example, it may be possible for a student to judge the shortness of a title, but the story is different regarding the attractiveness which is not necessarily a self-evident concept.

Undoubtedly due to the view of language as a transparent medium - a reflector of meanings rather than a situated discourse - feedback sessions often take the form of a prescriptive 'presentation' of general principles regarding the academic writing activity. For instance, in a feedback session organised around assignment on letter writing, the lecturer randomly picks up a student letter which becomes object of comments from both the lecturer and the students who take the opportunity to raise issues they are confronted with during their writing tasks. Questions such as the following are asked: 
How to know the form of greeting to adopt when writing a business letter? Is there special punctuation for a letter? When does one use 'sincerely yours' or 'faithfully yours' in the leave-taking part of a letter...? (24/03/2011)

The first and second questions above, calling for analysis of a sample of authentic written letters if not a practical exercise of letter writing, receive as lecturer's response a simple listing of "some tips" on 'Letter Writing and CVs'. The teaching process which has started as a session dedicated to comments on student take-home assignment ends up becoming an advice-session with focus on letter structure as indicated by the extract below:

The title of the receiver for a formal letter is very important. Don't forget to put details you judge very useful for the wanted position: qualification, experience... Please, don't forget to sign.... The receiver's address must be put below the sender's address and toward the left margin; the salutation or greeting follows... The main part of a letter is the body... Short sentences are recommended for all letters, concision, and to the point. $(24 / 03 / 2011)$

Pieces of advice related to 'good letter' are provided but probably not in a very meaningful way to students. There is no attempt to establish critical reading activities for example. Indeed, as Martin and Rose (2008) suggest, "learning the field of academic texts involves reading (and writing) the language patterns in which it is expressed... The [scaffolding] pedagogy entails teachers guiding students through a detailed reading of texts [...], drawing attention to the organisation of texts and their language patterns (p.167)." Thus, the above-mentioned feedback session probably needs more focus on critical reading likely to enable students to develop a deeper understanding of the text type they are examining.

Further, these feedback sessions based on prescription of principles are focused on particular aspects of the text to the detriment of others. Thus, the surface aspects (including linguistic accuracy and text structure) seem to acquire too much attention in comparison with aspects such as the student writer's understanding and treatment of the topic (i.e. the writing content), the rhetorical purpose and register-related aspects (e.g. referencing conventions, use of disciplinerelated terminology, use of formal language, etc.) which are however so challenging to students.Thus, the surface aspects (including linguistic accuracy and text structure) seem to acquire too much attention. This is in comparison with aspects such as the student writer's understanding and treatment of the topic (i.e. the writing content), the rhetorical purpose and register-related aspects (e.g. referencing conventions, use of discipline-related terminology, use of formal language, etc.) which are however so challenging to students.For an overall view of typical comments made, an analysis of a sample of student assignment copies is made. A comparison of areas commented on can be represented as in the table below: 
Table 1: Overall view of typical comments made on student texts

\begin{tabular}{|c|c|c|}
\hline $\begin{array}{l}\text { Assignment question (or } \\
\text { the assumed } \\
\text { epistemological purpose) }\end{array}$ & $\begin{array}{l}\text { Typical comments made on } \\
\text { student texts }\end{array}$ & $\begin{array}{l}\text { Academic writing } \\
\text { area focused by } \\
\text { comments }\end{array}$ \\
\hline \multirow[t]{5}{*}{$\begin{array}{l}\text { 1) Write a short essay } \\
\text { persuading a friend to } \\
\text { study literature }\end{array}$} & $\begin{array}{l}\text { - Poor grammar (Improve your } \\
\text { grammar, Incorrect grammar, } \\
\text { Grammar please...!); } \\
\text { - Use of tenses! (Tenses...!) } \\
\text { - Spelling! }\end{array}$ & Linguistic accuracy \\
\hline & $\begin{array}{ll}\text { - } & \text { Poor paragraph! (Paragraph!)... } \\
\text { - } & \text { Underlining (or Circling) of } \\
& \text { words, phrases... (Questions } \\
& \text { marks...); } \\
\text { - } & \text { Sentence structures! (Sentence } \\
& \text { not clear; Topic sentence...?) } \\
\text { - } & \text { Attention punctuation... } \\
& \text { (Punctuation!) }\end{array}$ & Text structure \\
\hline & $\begin{array}{llr}\text { - } & \text { Vocabulary! } & \text { (Lexical } \\
\text { suggestions to } & \text { replace } \\
& \text { inappropriate words...) } & \end{array}$ & Language register \\
\hline & - Inaccurate classification & Content \\
\hline & 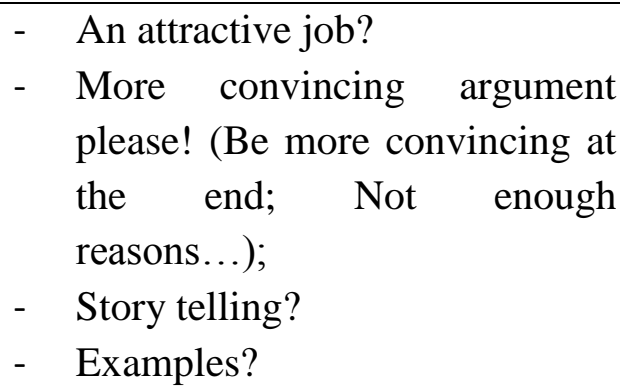 & Rhetorical purpose \\
\hline $\begin{array}{l}\text { 2) Write a short essay } \\
\text { (maximum } 3 \text { pages) } \\
\text { describing an event that } \\
\text { was significant in your }\end{array}$ & $\begin{array}{ll}\text { - } & \text { Tenses! } \\
\text { - } & \text { Spelling! } \\
\text { - } & \text { Grammar! (Pay attention to the } \\
& \text { use of grammar...) }\end{array}$ & Linguistic accuracy \\
\hline
\end{tabular}




\begin{tabular}{|c|c|c|}
\hline \multirow[t]{3}{*}{ life } & 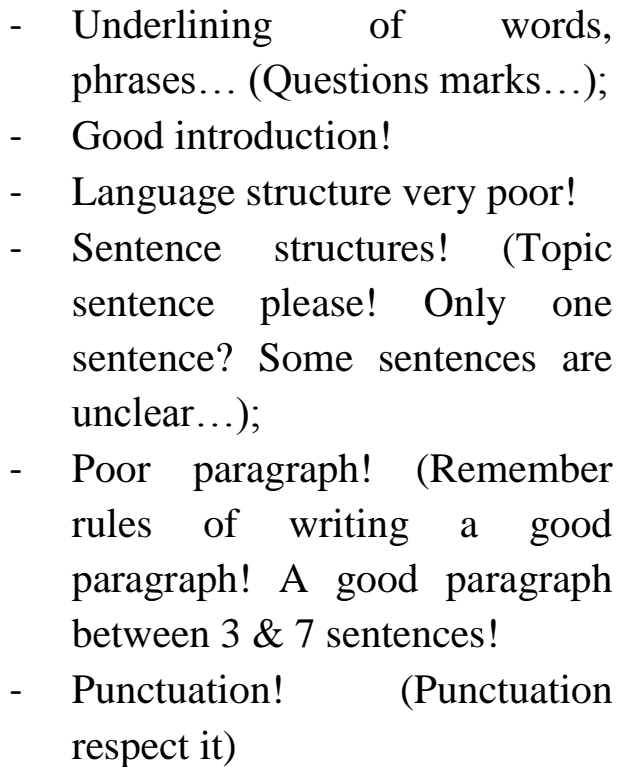 & Text structure \\
\hline & $\begin{array}{l}\text { - Your story not adapted to } \\
\text { English language: clear } \\
\text { influence of Kinyarwanda }{ }^{\text {xii. }}\end{array}$ & Language register \\
\hline & $\begin{array}{l}\text { - Problem of coherence(Problem } \\
\text { of coherence in your story...) } \\
\text { - } \quad \text { Meaning? } \\
\text { - } \quad \text { No point here }\end{array}$ & Rhetorical purpose \\
\hline
\end{tabular}

As is reflected in the table above, there is a lack of balance in the way in which different textual aspects are focused on by lecturers' feedback comments. The latter seem more focused on some straightforward aspects that are easy to spot (e.g. linguistic accuracy, text structure...) to the detriment of aspects that are however critical to the writing abilities expected of students such as the language register and rhetorical issues. Thus, in the case of the two assignment topics presented as illustrations, aspects related to the epistemological purpose of the assigned task (e.g. the form of the persuasive arguments presented and the description skills) seem to be given less importance by lecturer-markers.

It would be useful to note that the above synthesis of comments made on student texts does not constitute a full reflection of the assessment criteria used by lecturers as the assessment mode in place rather appears as much based on implicit criteria. So, the representation of 'typical 
comments' as shown by the table above can just be regarded as an indication of the general trend in the assessment system.

\subsection{A hierarchical relationship between lecturers and students}

Concerning language of feedback, it is worth reminding that dominance of negative feedback comments is remarkable. That is, lecturers' comments on students' work are mainly characterised by criticism which is much focused on shortcomings in students' texts. For example, each script in a sample of 22 student scripts drawn for analysis in the current study has its lot of negative comments such as 'poor paragraph', 'bad sentences', 'faulty grammar', no point made, etc. which are rather generic and do not seem to help students understand where the problem is exactly. There is in fact a tendency to over-negative comments which are likely to undermine students' confidence as writers. Further, the language of feedback used reflects a relatively hierarchical and rather didactic relationship in which the power differential between lecturers and students is emphasised as illustrated by the student script below: 


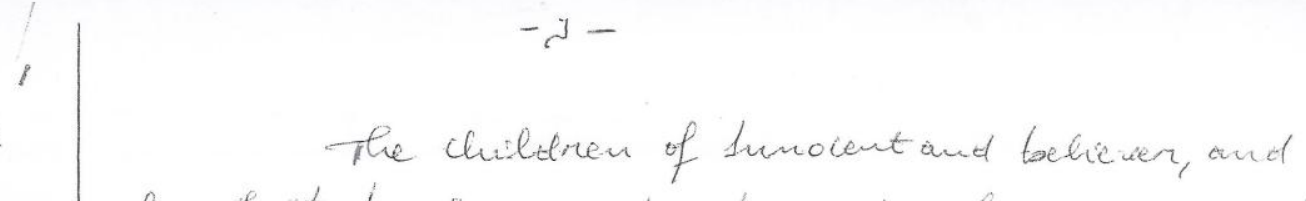

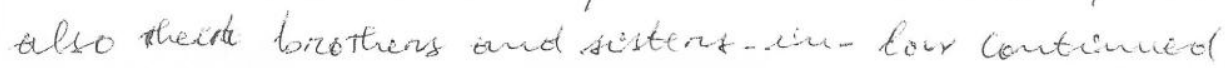

$$
\begin{aligned}
& \text { to be in the povenmanemt of those tric condeted }
\end{aligned}
$$

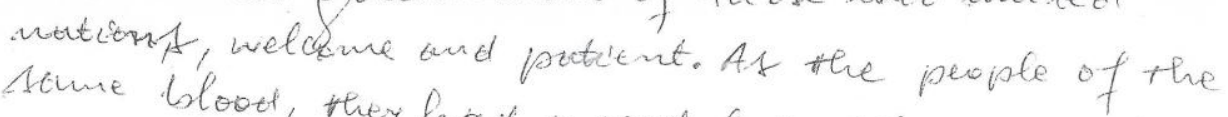

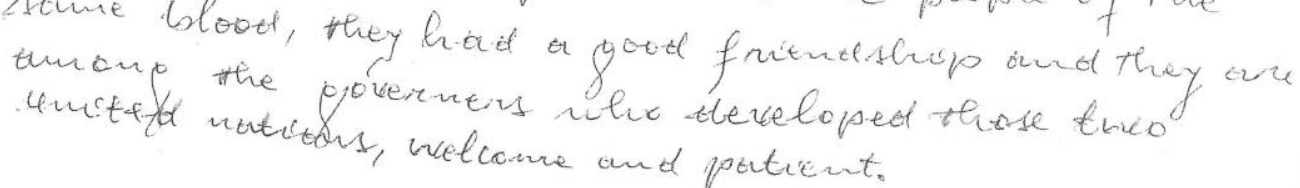

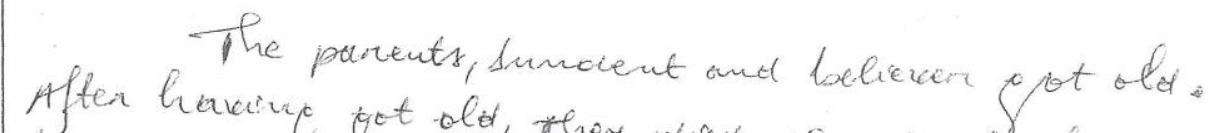

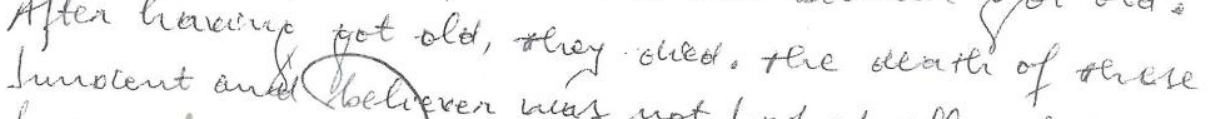

$$
\begin{aligned}
& \text { becourse they died offer havernet bad at all. Thes is }
\end{aligned}
$$

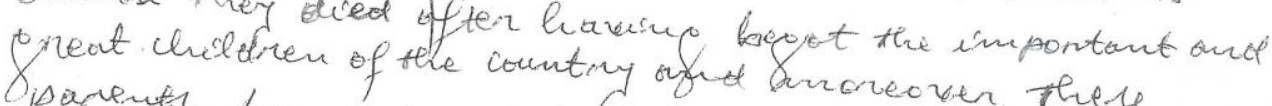

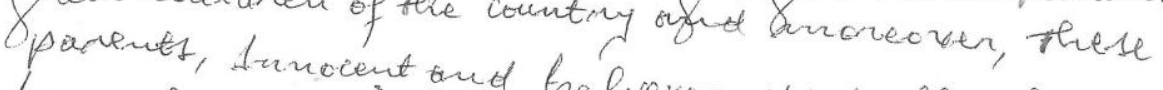

$$
\begin{aligned}
& \text { tocen olol. }
\end{aligned}
$$

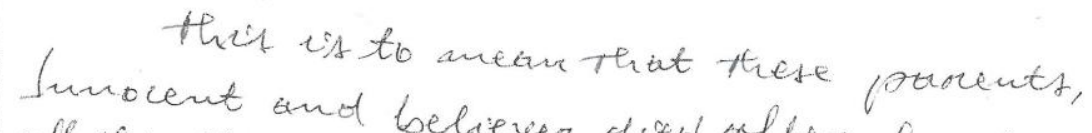

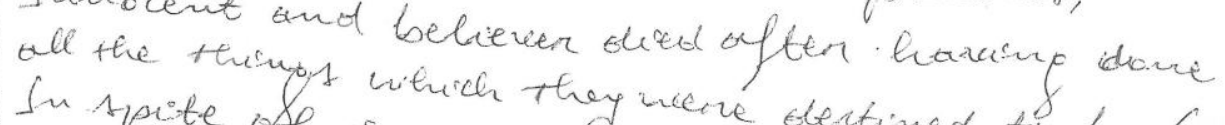

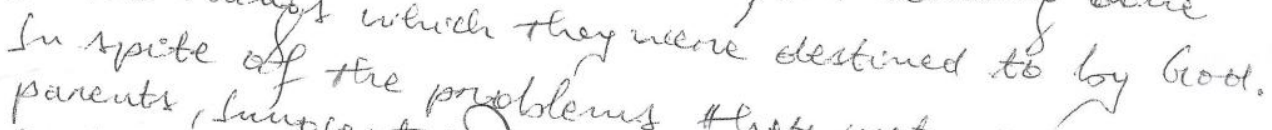

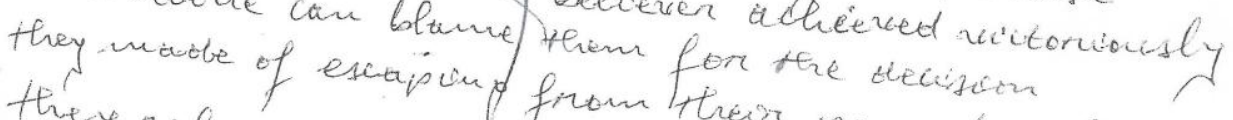

$$
\begin{aligned}
& \text { they nefisid them to firom them partents otien }
\end{aligned}
$$

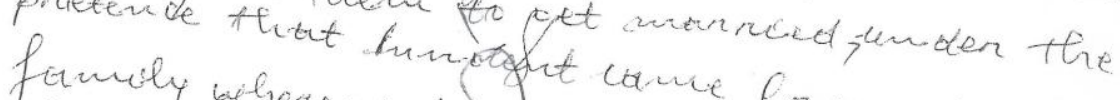

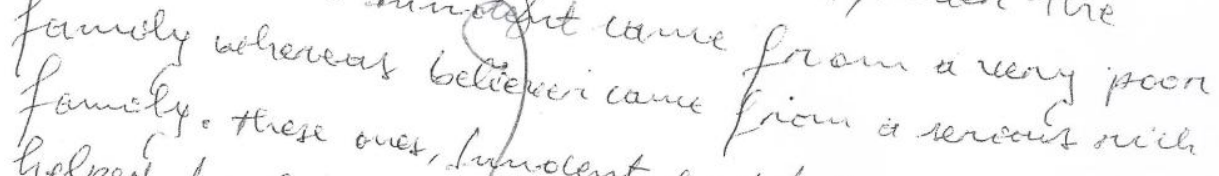

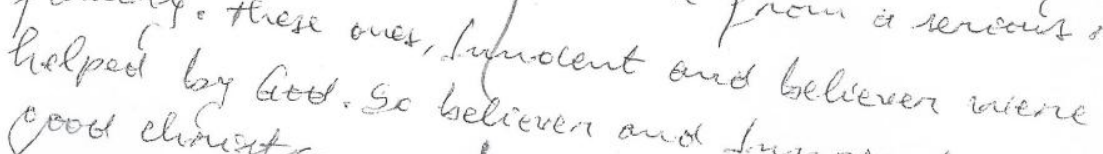

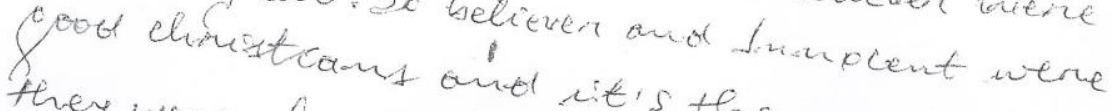

$$
\begin{aligned}
& \text { they werne bucky... No point herel reasion that }
\end{aligned}
$$


As shown by the hand-written copy above, the type of feedback made on the student copy cannot be considered as a type of "judgment" meant either to indicate the right performance expected of the students or the way of improving the poor performance characterising the text produced. With only question marks on the copy, there is little possibility for the student-writer to understand what is required of him/her to gain membership in the academic community (Ivanič et al., 2000).

In overall, there is very limited features likely to encourage a relatively collegial relationship between lecturers and students. For example, the sample of copies drawn during the observation period shows comments generally written in red pen over the students' texts ${ }^{\mathrm{xii}}$. These comments are generally devoid of positive comments likely, as Ivanič et al. (2000) put it, to foster a more collegial relationship in which the lecturer attempts to "build students' sense of membership of the academic community" (p. 61). Indeed, there is a need of comments that are likely to create students' awareness of relevant discourse features and, hence, help positively accommodate them into the academic community.

\subsection{Not engaging students in the authorship of their work}

As already alluded to, feedback is likely to be more beneficial when presented in a way that draws students' attention to the comments made on their work. This seems to be a challenge to the investigated module where students do not appear very attentive to the feedback provided on their written work. As noticed during the observation period, students do not appear much interested in feedback comments made on their assignment copies. They are only interested in the final mark obtained. The case of the writing assignments of $31^{\text {st }}$ March 2011 may serve as illustration. Students had been asked to submit a short essay on a topic of their choice among three topics offered by the lecturer. After the lecturer made his written comments, the scripts were returned and handed over to students individually. There was no word about the global performance of the class in relation to that particular assignment. Thus, in front of the remarkably terse written comments, students with low marks were apparently not sure about what was wrong with their texts. Each individual student went straight to the final mark awarded to his/her script, sighed with relief or sorrow (according to whether or not the obtained mark was good) and kept quiet. Such a situation is frequent and is not likely to help students benefit from 
feedback they get from their lecturers. Instead, they seem frustrated by what they get as outcome of their work.

Furthermore, implementation of the newly established modular system does not always facilitate a systematic track and solution of students' problems. It is indeed supposed to merge together different course units (i.e. Grammar, Reading and writing strategies, and Essayist writing) taught by different lecturers.But, the investigated module does not seem to be coordinated in a way that helps address the issue of contradictions emerging from the successive interventions of the three members of the teaching team. Thus, students are confronted not only with possibility of conflicting demands from the teaching team but also with lack of follow-up on their learning difficulties as problems left in suspense by a lecturer are not necessarily taken into account by the lecturer meant to take over for the following session. The undecided fate of the take-home assignments proposed during Week Two (24/02/2011) and Week Six (17/03/2011) may serve as illustrations. Further, students' confusion subsequent to existing contradictions was noticed during the observation period but also was echoed by interviews with students who affirm that they try to play it safe with the lecturers' conflicting demands by refraining from taking responsibility in their writing.

\section{Discussion of findings}

On examination of what is going on in the classroom, lecturers' feedback comments are generally focused on some straightforward aspects that are easy to identify (e.g. linguistic accuracy, text structure...) to the detriment of aspects that are however critical to the writing abilities of students such as language register, rhetorical issues, adaptation to the audience, etc. Feedback on students' written texts generally reflects a discourse of transparency whereby conventions within which students are supposed to write are taken as given. This is demonstrated by the form of feedback made on students' script whichis characterised by a monologic communication and authoritative attitude often negatively challenging students' attempts to express their voice in their writing.

Also, feedback practices fore-grounded by lecturers are based on hierarchical and didactic relationships and do not appear proper to engage students in the authorship of their writing. In fact, as suggested by research findings on the subject (see Conrad \& Goldstein, 1999), teacher 
feedback comments that challenge students' logic or type of argumentation are likely to have a negative impact on novice-writers. Further, both L1 and L2 composition researchers reported by Ferris (2003) have warned teachers against “appropriating (taking over) students' texts by being too authoritative and direct in their feedback" (p.124). As suggested by Ferris (ibid.), "When teachers cross out portions of students texts and substitute other words or ideas, make directive suggestions, or use the imperative mood, these behaviourscommunicate to student-writers that the teacher's priorities are more important than what the writer wants to say in his or her own text" (p. 124). Ferris notes that "such appropriative behaviour can frustrate, demotivate, and otherwise disempower student writers" (p.124).

Thus, there is a need for feedback based on a closer communication or dialogue between lecturers and students. For such a dialogue to be formalised, feedback comments should not be seen as an end in themselves. They should rather be inscribed in a longer process whereby students' difficulties are discussed and the first text serves as a basis to produce an improved version of it. Instead of focusing on shortcomings in students' texts, discussion sessions will help create awareness of relevant discourse features and, hence, positively accommodate students into the academic community.

Further, a dialogue approach would foster a constant follow-up on students' completion of their assignments which is so relevant in the case of the investigated module. Follow-up on student assignments implies strategies to constrain students to complete tasks left to them. As suggested by Coffin et al., (2003), such strategies can consist of considering "a summative assessment with a low weighting attached to it" (p.77). So, the type of assignments mentioned above may be conducted with an option whereby a formative assessment (i.e. teaching feedback to students' assignments) is combined with a summative assessment (i.e. awarding of grade to student work).

The investigationof classroom activities confirms that students have yet to take on the authorship of their writing and assert their voice as members of the university community. There is also a need for lecturers to feel more in charge of guiding their students through an understanding dialogue allowing them to build on their knowledge and experience for progressively asserting their identity as members of academia. Indeed, an effective involvement of students in the authorship of their own texts is deemed critical to gain the required ability for meaning making 
in their texts (Ivanič, 1998). Under such conditions, the teaching endeavour is also likely to achieve what Coffin et al. (2003) refer to as 'handover', that is, "the point at which the 'expert' tutor or lecturer hands over responsibility to the students for writing" (p. 127).

Also, the issue of authority and power relations is pervasive. This is with reference to a particular enactment of conventions of academic discourse that may not allow students to feel personally connected to their texts (Lillis, 2001). Some of the students interviewed in focus group affirmed that they sometimes did not feel to be themselves in their academic essays. One of the students who presented himself as a poet in his mother tongue regretted to feel in shortage of inspiration when he is writing academic texts as he has to exercise self-censorship not only regarding the content which must be carefully selected but also regarding the form of his expression which must take account of what is to be judged as good by the lecturer-marker.

The image of lecturer as infallible judge is also illustrated by the above-described exercise consisting in making distinction between standard and non-standard sentences (Week One) where the lecturer seemed to impose the "correct answer" without necessarily providing enough explanations to students. Such an image is also suggested by the fact that solutions to some exercises given to students in classroom are not necessarily discussed with students, or the fact that assignment guidelines, usually formulated by the lecturer, are not subject of negotiations between lecture and students. As consequences, students used to such a 'normative form' of teaching generally relied on initiatives from the lecturer. They did not question some newly introduced notions they did not understand for example.

In the context of ESL as is the case for the investigated module, this failure to make plain what is to be learnt has consequences to students. These students who usually do not even have familiarity with the common communicative conventions and lack knowledge of the typical patterns of variation within English text types, find themselves in an "invisible curriculum" (see Hyland, 2003) as they are denied access to the rules of the discourse which is indispensable for their success. Indeed, as shown by the analysis of the teaching practices made on basis of Bernstein's $(1977,2003)$ model of pedagogic discourse, instructional rules prevailing in the investigated module contribute to the creation of a typical model of invisible curriculum. That is, while it should be expected that students are provided with abilities of using conventions of 
academic writing, the latter continue to be treated by lecturers as self-evident and are not generally made explicit to students. This is reflected not only by the pedagogical activities proposed in the classroom but is also illustrated by the feedback practices used by lecturers.

\section{Conclusion}

Through the critique made of the existing feedback model, the present study advocates a writing pedagogy where students will be empowered for taking over the authorship of their writing. To such an end, an institutional transformation enabling more creative and egalitarian teaching and learning practices is needed. Further, findings of the study reaffirm, among other facts, the imperative of fore-grounding a dialogue between lecturers and students around the writing activity, and the necessity to address the issue of differing perceptions and expectations with regard to student written texts. This issue of differing perceptions and expectations could be resolved through teaching practices emphasising a transparent and explicit definition of 'criterial rules' (Bernstein, 1977, 2003) governing the academic writing discourse.

Thus, for an academic writing course such as the one investigated, a shift in pedagogy implying moving away from concentration on form aspects appears of great relevance. Such pedagogy would be based on the principle that a written text is a complex unity of diverse voices and that the student-writer, as suggested by Scott and Turner (2004), is bearer of "the voices of past instruction, the voices of current tutors, the loud of faint voices of the student's assumptions and expectations regarding writing in English" (p. 152). This principle would thus help address the issue of the "in-between space" many students are faced with as they need for example to negotiate at the same time the meaning of a source text and conventions governing "essay text literacy" as emphasised by academic practices of HE (Scott \& Turner, 2004, p. 146).

The fact of the matter is that focus on form aspects of a written text is likely to distract attention from the need to understand and negotiate the socio-linguistic, cultural, economic, and interactive dimensions linked to the writing context (see Lei, 2008; Matsuda, 1997). Indeed, a teaching model focusing on form aspects contributes to misleading student-writers about the necessary balance between, on one hand, language features such as grammar, spelling and register-related aspects and, on the other hand, elements related to content, purpose, adaptation to audience, etc. It is also worth noting that structure errors in students' writing are often 
symptomatic of difficulties due to a lack of familiarity with a particular disciplinary discourse (see Nightingale, 1988).

So, a teaching model shifting focus from form aspects of the written text would open more space for a "dialogue of participation" (Lillis, 2006) with students to ensure their familiarity with discourse strategies regarding elements such as audience expectations, genre characteristics with respect to different disciplinary contexts, etc. As suggested by Lillis (2003), it is important for teachers to provide opportunities of dialogue with students about the type of meanings they might wish to make in their academic writing, instead of imposing particular meanings based on categorically rigid feedback about "one version of truth" while there may exist "a range of possible truths and interpretations" (p. 198).

\section{References}

Angelil-Carter, S. (1998). Access to success: Academic literacy in higher education. Cape Town: University of Cape Town Press.

Baxter, A. (2012). Higher education mission and vision in Rwanda: A comparative and critical discourse analysis. Re/Considering Development, 1(1). Retrieved September 26, 2012, from http://journal.ipid-umn.org/node/201

Bernstein, B. (2003). Class, codes and control: The structuring of pedagogic discourse (Volume IV). London and New York: Routledge.

Bernstein, B. (1977). Class and pedagogies: Visible and invisible. In A. H. Halsey, \& J. Karabel (Eds.), Power and ideology in education (pp. 511-534). New York: Oxford University Press.

Brown, G., Bull, J., \& Pendlebury, M. (1997). Assessing student learning in higher Education. London: Routledge.

Coffin, C., Curry, M.J., Goodman, S., Hewings, A., Lillis, T., \& Swann, J. (2003). Teaching academic writing: A toolkit for higher education. London and New York: Routledge.

Conrad, S., \& Goldstein, L. (1999). ESL student revision after teacher written comments: Text, contexts, and individuals. Journal of Second Language Writing, 8, 147-180.

Ferris, D. R. (2003). Treatment of error in second language student writing. Ann Arbor: University of Michigan Press. 
Ivanič, R., Clark, R., \& Rimmershaw, R. (2000). What am I supposed to make of this? The messages conveyed to students by tutors' written comments. In M.R. Lea, \& B. Stierer (Eds.), Student writing in higher education: New Contexts.Buckingham: Society for Research into Higher Education and Open University Press.

Ivanič, R. (1998). Writing and identity: The discoursal construction of identity in academic writing. Amsterdam: John Benjamins.

Lacono, J., Brown, A., \& Holtham, C. (2009). Research methods - a case example of participant observation. Electronic Journal of Business Research Methods, 7(1), 39-46.

Langer, J., \& Applebee, A. (2007). How writing shapes thinking: A study of teaching and learning. Urbana, Illinois: NCTE.

Lea, M. R., \& Street, B. V. (1998). Student writing in higher education: an academic literacies approach. Studies in Higher Education, 23(2), 157-172.

Lei, X. (2008). Exploring a sociocultural approach to writing strategy research: Mediated actions in writing activities. Journal of Second Language Writing, 17(4), 217-236.

Lillis, T., \& Turner, J. (2001). Student writing in higher education: Contemporary confusion, traditional concerns. Teaching in Higher Education, 6(1), 57-68.

Lillis, T. (2006). Moving towards an 'academic literacies' pedagogy: Dialogues of participation. In L. Ganobcsik-Williams (Ed.), Teaching academic writing in UK higher education: Theories, practices and models (pp. 30-45). New-York: Palgrave MacMillan.

Lillis, T. (2003). Student writing as 'academic literacies': Drawing on Bakhtin to move from critique to design. Language and Education, 17(3), 192-207.

Lillis, T. (2001). Student writing: Access, regulation, desire. London and New York: Routledge.

Lillis, T. (1997). New voices in academia? The regulative nature of academic writing conventions. Language and Education, 11(3), 182-199.

Martin, J., \& Rose, D. (2008). Genre Relations: Mapping Culture. London: Equinox Publishing.

Matsuda, P. K. (1997). Contrastive rhetoric in context: A dynamic model of L2 writing. Journal of Second Language Writing, 6 (1), 45-60. McMillan \& Schumacher. 2006

MINEDUC. (2010). Education sector strategic plan (ESSP) 2010-2015: Appraisal. Kigali: Ministry of Education. 
NCHE. (2007a). National policy on language teaching in higher education. Kigali: the author. Retrieved November 12, 2010, from http://www.hec.gov.rw/spip.php?article243

NCHE. (2007b).Rwandan higher education. Kigali: the author. Unpublished document.

NCHE. (2007c). Rwandan national qualifications framework for higher education institutions. Kigali: the author. Retrieved October 10, 2011, from http://www.hec.gov.rw/IMG/pdf/Rwanda_National_Qualifications_Framework_for_Hig her_Education_Institutions-2.pdf

Nightingale, P. (1988). Understanding processes and problems in student writing. Studies in Higher Education, 13(3), 263-283.

National University of Rwanda. (2009). Academic quality manual 2: Academic policies and regulations (Adopted by NUR Senate 2008 and revised 2009 for new undergraduate and master's programmes). Butare: NUR.

Rosendal, T. (2010). Linguistic landshapes: A comparison of official and nonofficial language management in Rwanda and Uganda, focusing on the position of African languages. $\mathrm{PhD}$ Thesis. University of Gothenburg, Gothenburg.

Rosendal, T. (2009). Linguistic markets in Rwanda: language use in advertisements and on signs. Journal of Multilingual and Multicultural Development, 30(1), 19-39.

Scott, M., \& Turner, J. (2004) Creativity, conformity and complexity in academic writing: tensions at the interface. In M. Baynham, A. Deignan and G. White (Eds.), Applied Linguistics at the Interface. British Studies in Applied Linguistics19

World Bank. (2011). Rwanda education country status report: Toward quality enhancement and achievement of universal nine year basic education. Washington, D.C.: World Bank.

Zamel, V. (1998). Strangers in academia: The experiences of faculty and ESL students across the curriculum. In V. Zamel, \& R. Spack (Eds.), Negotiating academic literacies: Teaching and Learning across languages and cultures (249-264). Mahwah, New Jersey: Laurence Erlbaum Associates, Inc. 